\title{
Miia Huttunen
}

\section{UNESCO'S CINEMATIC MULTIVERSE AND THE BEST OF ALL POSSIBLE WORLDS}

\begin{abstract}
FM Miia Huttusen valtio-opin (kulttuuripolitiikan) väitöskirjan "Suitable for Western Audiences: UNESCO and the Self-fulfilling Prophecy of Cinematic Cultural Diplomacy" tarkastustilaisuus pidettiin Jyväskylän yliopistossa 28. toukokuuta 2020. Vastaväittäjänä toimi professori J.P. Singh (George Mason University, USA) ja kustoksena professori Pekka Korhonen (Jyväskylän yliopisto).
\end{abstract}

In the TV adaptation of Philip K. Dick's novel The Man in the High Castle, the Axis Powers have won World War II. The TV series depicts a parallel universe, in which America is dominated by Nazi Germany and Imperial Japan. The Nazis hunt minorities and routinely murder the sick and disabled, while the Japanese rulers openly practice racial discrimination. Amid the dystopian terror that is life under totalitarian rule, a young woman discovers a film reel that seems to hold the power to question the assumed natural order of her world. The film she finds shows a version of the post-war world in which the war was won by the Allies. While the film does not have the power to overthrow the oppressive regimes that rule what could have been the free world, it creates a critical space for reflecting upon our expectation that things will always be the way they are now, and that the world we know is the only possible world. Simply put, in The Man in the High Castle, film holds the capacity to show us alternative realities.

Now let us imagine for a moment that at a time of war, crisis and conflict or the chaos and confusion that follows, we have - for dramatic effect - two extreme positions we can choose to observe the situation from. We can choose to sit back, watch the world burn and say I told you so. Or, we can choose to stand up and say: "Even though we couldn't stop this from happening this time, we will do everything in our power to make sure it never happens again". While I am by no means blind to the seductive appeal of being able to say I told you so and thus deny any responsibility for what has taken place or what might happen in the future, this is a rather hopeless take on the world. Like the young woman in The Man in the High Castle, the heroes in the story my PhD thesis tells have chosen the other path.

My thesis has nothing to do with Philip K. Dick. It has a little to do with the Nazis, and everything to do with the potential cinema holds for imagining change. My thesis tells the story of an instance when cinema was put to use to imagine yet another version of the post-World War II world - one quite strikingly different to the one depicted in The Man in the High Castle. 
It is a story of a world that is divided into two based on the practicalities of cultural differences, but united through universally shared values. It is a story of an alternative world in which within these differences lies not a source of war and conflict, but one of peace. It is a story of a world imagined by UNESCO through the means of cinema.

The United Nations Educational, Scientific and Cultural Organization UNESCO was founded in the aftermath of World War II to build the foundations of peace "upon the intellectual and moral solidarity of mankind" (UNESCO 1945) and - here is the Nazi connection as promised - to provide a counterforce to the propaganda of the Axis powers. The need for UNESCO's existence is argued for through a belief that ignorance and misunderstanding, based primarily on cultural factors, are the underlying reason behind wars and conflict. UNESCO's role on the world political stage is to function as a mediator between nations and cultures, and as a preventative force against the problems arising from the differences between them. At the organisation's founding conference, British prime minister Clement Attlee explained:

Today the peoples of the world are "islands shouting at each other over seas of misunderstanding." They do not understand each other's history, each other's ways of living, each other's way of thinking. The better they understand each other, the more they will realise how much they have in common and why and how much they differ, the less prone they will be to take up arms against each other. (UNESCO 1946, 22)

Standing in the ruins of World War II, the founders of UNESCO categorically refused to give up hope, but instead took on the task of guiding humankind towards a future of peace. In his speech, prime minister Attlee proposed that the way towards a more peaceful conduct of world affairs was through understanding. Understanding, as it was to be seen by UNESCO, was not only a question of what we have in common, but also of the points where we differ. It was therefore the notion of cultural differences and the imperative to prevent their worst outcomes that UNESCO was born out of. Recognising that cultural differences existed as instruments for dividing the world into opposing camps, UNESCO's next move became more a question of what to do with them and how.

The UNESCO constitution sets its hopes upon the possibility of influencing the attitudes and opinions of the peoples of the world holding the power to bring about a world of peace. Its opening line says: "That since wars begin in the minds of men, it is in the minds of men that the defences of peace must be constructed" (UNESCO 1945). In my thesis, I argue that the part of the minds of men that UNESCO seeks to influence is their misguided, negative attitudes towards cultural differences. But how exactly would one go about changing the minds of men in practice?

For the past couple of decades, a growing number of scholars have turned to popular culture, most notably cinema, to address global political issues. Even though cinema relates to both the study and practice of world politics in various multidimensional ways through, for example, questions of representation, cultural consumption and identity, this relationship is perhaps the most visible in the way cultural products can be put to use as instruments in political and ideological disputes.

Cinema is a site of meaning making, which through its depiction of imaginary worlds not only arises from, but also adds to, its cultural, social and political surroundings. Not only does it construct and carry meanings of its own, but it can also be harnessed to mediate messages that we choose to attach to it through the ways we frame it, talk about it or use it for specific purposes. Utilising cinema to change attitudes and influence opinions has a slightly nasty ring to it. It makes us think of censorship, or even worse, propaganda. It sounds like taking something innocent and pure, and perverting it for overtly political purposes. In my thesis, I wanted to show that taking a collection of seemingly apolitical films and using them as an instrument for serving explicit political aims can also be used as a force for good. 
In order to address the issues of difference and the part they were seen to play in UNESCO's world, UNESCO, together with the British Film Institute, published a catalogue of films produced in UNESCO's Eastern member states in 1959. The catalogue was titled Orient: A Survey of Films Produced in Countries of Arab and Asian Culture. The catalogue included 348 feature films, short films and documentaries from 21 countries. The aim of the catalogue was to "stimulate the presentation of films which might give audiences in the West a fuller and more informed idea of the ways of life of Eastern peoples". In other words, with the film catalogue UNESCO sought to promote intercultural understanding between the East and the West.

Now, one might assume that a project with such an aim would take any means necessary to emphasise the similarities between the two halves of the world it was supposed to promote understanding between - I know I did. Instead, the catalogue does the exact opposite. "To Western audiences, some of the films listed here will seem strange, even incomprehensible", the catalogue warns (Holmes 1959). The catalogue lists seven characteristics of Eastern cinema extracted from the collection of films included in it. The list covers a wide array of social phenomena ranging from the perceived stronger emphasis on struggle in the Eastern films to the way love, sex, sentiment and emotion are treated, from depictions of courtesy in human relations to the role of music in the films, and from the attributes of the standard female character to representations of violence. Simply put, the catalogue speaks of cultural differences as manifested through these films as a way of separating the East from the West.

The relationship between cinema and world politics does not necessarily manifest itself in a clear, overt manner. It is the sneaky, indirect forms that this relationship takes on that arguably hold the greatest power and, to be honest, are the scariest of all. Popular culture holds the ability to make a specific way of understanding the world seem to be beyond questioning - as just the way things are. Thus, cinema can function as a means of maintaining and rein- forcing existing conceptions - such as the understanding of cultural difference as a potential site of conflict. Stating, for example, as the catalogue does, that in Eastern cinema, "Violence usually has a heroic tinge, connected with the traditional warrior codes which foster national pride" (Holmes 1959) warns us of the dangerous connection between national cinema, national culture and national pride, which in the world of UNESCO reflects the factors that made the past wars possible in the first place. Thus, on the surface, UNESCO's Orient catalogue seems to maintain the very same notion it is trying to fight against as its starting point clearly is that the East and the West differ from each other to such an extent that understanding between the two must be promoted.

In The Man in the High Castle, more films start appearing, all of them depicting a different version of the world. The Orient catalogue suggests the existence of a similar multiverse, where there is always another version of the world to be discovered around the corner. This is perhaps the clearest in the way the catalogue constructs the world it emerged from. The Orient catalogue was published during the early, ideologically heated stage of the Cold War and at the peak of the decolonisation process. The catalogue's starting point of dividing the world into two along a border between the East and the West thus clearly had geopolitical, ideological and civilisational grounds. On the surface, the catalogue seems to depict the political reality of the post-war world.

Under the surface, however, UNESCO's understanding of the world as it was imagined in the film catalogue was far more complex and, in fact, quite radical. The films in the Orient catalogue were supposed to reveal "whole new regions of thought, feeling and action" to the Western world. The films depict the East as the national representatives in charge of choosing the films decided it was to be depicted, be it an attempt to renegotiate a nation's position in the international arena, to portray the struggles of a post-colonial nation, or to promote the ideals of the Soviet socialist empire.

More importantly, the way the films are 
described in the catalogue depicts yet another East - one imagined into being by UNESCO. It is an East filled with adventure and spectacle. No matter where you look, there are maidens to rescue, honour to defend and rebels to fight. It is an East of exotic heroes, dancing, and swordfights. There is something intriguing and novel about the Eastern world, and these films hold the power to introduce it to Western audiences. Yet, at the same time, there is something strangely familiar about the East. It is an East struggling with its attempts to adapt to the changing societal conditions of the post-war world and the uncertainty brought about by newly found independence after generations under colonial rule. It is an East that shares with the West the values of understanding, solidarity and hope as the fundamental building blocks of how social interaction is organised.

Thus, while the catalogue acknowledges the underlying similarity between the East and the West, it still puts a considerable amount of effort into maintaining and even reinforcing the differences between them. The films in the Orient catalogue then serve to connect across the difference they supposedly reveal.

The catalogue uses the films to speak of the East and the ways it differs from the West in a way that arouses our curiosity. We, the Western audiences, should look at the East as different enough to find it exotic and intriguing and consider it as something worth appreciating. Presented like this, the cultural differences between the two halves of the world become a positive. Difference in the Orient catalogue is not, however, shrunk to a mere source of evoking interest or appreciation. With the Orient catalogue, UNESCO clearly acknowledges that dialogue between cultures can be established and intercultural understanding promoted only if cultures are categorically seen as different. Thus, the world the catalogue depicts must be one constructed upon cultural difference. Cultural difference, in other words, becomes a necessary condition for structuring UNESCO's world and understanding the positions of the people in it.

It then makes perfect sense that it is not on UNESCO's agenda to attempt to erase these seemingly problematic differences or even to smooth them over. Instead, I argue in my thesis, what UNESCO is trying to teach us is that the primary source of war and conflict is misguided, negative attitudes towards cultural differences, not the differences themselves.

Therefore, even if the fictional narratives of popular culture can maintain and reinforce our existing conceptions of how the world is, they can luckily also do the exact opposite. Popular culture can serve as a means of unseating what we think of as common truths that we find difficult to argue against. Turning to cinema to argue for a paradigm shift in the ways we understand the functions of difference is undoubtedly a prime example of such an intervention.

Ultimately, in my thesis I argue that with the Orient catalogue, UNESCO turned to the disruptive power of cinema to question the link between difference and conflict, and suggested that instead, we should celebrate difference as an imperative asset in the construction of a peaceful world. Thus, my thesis addresses the significance of understanding how the products of popular culture create, recreate, critique, and challenge our understanding of how the world is, and how UNESCO has used them to do so. Because - believe it or not - popular culture can change the world.

As I have noted in my thesis, for the founders of UNESCO, the best of all possible worlds was not this one, but one just around the corner. That world was one we could imagine through cinema. UNESCO's Orient catalogue, like The Man in the High Castle points to the possibility of multiple possible worlds, each one of them equally real. In a world with countless options of what can be imagined as real, no intervention - no matter how noble, radical and well intentioned its aims - can be thought of as definite. With the catalogue, UNESCO argued for the realisation of its vision of a better world. Yet, it recognised that this was not the only possible outcome. In other, equally real, possible worlds the dreaded consequences of ignorance, misunderstanding and distrust that UNESCO was fighting against might continue to thrive or grow even stronger. This is precisely why we still 
need organisations such as UNESCO to push us to imagine alternative ways of living together in this world or in the countless versions of it that could someday be.

\section{References}

Holmes, W. (1959). Orient. A Survey of Films Produced in Countries of Arab and Asian Culture. Prepared by Winifred Holmes for the British Film Institute. London: British Film Institute.

UNESCO (1945). UNESCO Constitution.

UNESCO (1946). Conference for the Establishment of the United Nations Educational, Scientific and Cultural Organisation. UNESCO Preparatory Commission, document ECO/CONF/29. Paris: UNESCO. 